\title{
Membrane Estrogen Receptor Regulation of Hypothalamic Function
}

\author{
Paul E. Micevych ${ }^{\mathrm{a}}$ Martin J. Kelly ${ }^{\mathrm{b}}$ \\ aDepartment of Neurobiology, Brain Research Institute, David Geffen School of Medicine, University of California \\ Los Angeles, Los Angeles, Calif., and ${ }^{\mathrm{b}}$ Department of Physiology and Pharmacology, Oregon Health and Science \\ University, Portland, Oreg., USA
}

\begin{abstract}
Key Words
$17 \beta$-estradiol - Estrogen receptor alpha - Estrogen receptor beta $\cdot$ GPR30 (GPER1) - G $\alpha$ q-coupled membrane estrogen receptor · mGluR1 receptor - Gonadotropin-releasing hormone neuron $\cdot$ Proopiomelanocortin neuron
\end{abstract}

\begin{abstract}
Over the decades, our understanding of estrogen receptor (ER) function has evolved. Today we are confronted by at least two nuclear $E R s$, $E R \alpha$ and $E R \beta$, and a number of putative membrane ERs, including ER $\alpha$, ER $\beta$, ER-X, GPR30 and Gq$\mathrm{mER}$. These receptors all bind estrogens or at least estrogenic compounds and activate intracellular signaling pathways. In some cases, a well-defined pharmacology and physiology has been discovered. In other cases, the identity or the function remains to be elucidated. This mini-review attempts to synthesize our understanding of $17 \beta$-estradiol membrane signaling within hypothalamic circuits involved in homeostatic functions, focusing on reproduction and energy balance.

Copyright $\odot 2012$ S. Karger AG, Basel
\end{abstract}

\section{Introduction}

$17 \beta$-estradiol $\left(\mathrm{E}_{2}\right)$ modulates circuits regulating reproduction, energy balance, temperature, circadian rhythms and stress, and provides neuroprotection in cas- es of neurodegenerative diseases and trauma $[1,2]$. In addition, ovarian and neurosteroidal $\mathrm{E}_{2}$ are involved in structural plasticity in the hippocampus that influences cognitive behaviors [3]. $E_{2}$ signaling is one of the most fundamental aspects of reproduction. In females, it is the basis of positive and negative feedback within the hypothalamic-pituitary-ovarian axis. $\mathrm{E}_{2}$ produced by the ovary signals the endocrine status of gonads to the brain and activates circuits that regulate ovulation. Through the activation of a neural-glial network, $\mathrm{E}_{2}$ induces the release of gonadotropin-releasing hormone $(\mathrm{GnRH})$ and luteinizing hormone $(\mathrm{LH})$, and stimulates sexual behavior. Thus, $E_{2}$ increases the probability that the ovulated egg will be fertilized. To achieve these effects, $\mathrm{E}_{2}$ binds to and activates estrogen receptors (ERs).

Our ideas about what constitutes an ER are constantly evolving as we understand more about the actions of $E_{2}$, especially in the nervous system. Before ER proteins were characterized and cloned, ERs were defined by their ability to bind estrogens and elicit a specific response [4]. Early, ER was considered a cytosolic receptor that upon $\mathrm{E}_{2}$ binding underwent a conformational change and translocation to the nucleus where it interacted with DNA to regulate the expression of particular genes through DNA motifs known as the estrogen (receptor) response element (ERE). It became clear that even in the absence of $E_{2}$, ERs were located in the nucleus, suggesting that ERs were synthesized in the cytoplasm, but preferentially transported back into the nucleus. Upon cloning, the nuclear ER was

\section{KARGER}

Fax +4161306 1234

E-Mail karger@karger.ch

www.karger.com
(C) 2012 S. Karger AG, Basel

$0028-3835 / 12 / 0962-0103 \$ 38.00 / 0$

Accessible online at:

www.karger.com/nen
Paul E. Micevych, PhD

Department of Neurobiology, David Geffen School of Medicine

University of California Los Angeles

Los Angeles, CA 90095-1763 (USA)

E-Mail pmicevych@mednet.ucla.edu 
determined to be two proteins, ER $\alpha$ and ER $\beta$, coded by different genes: ESR1 and ESR2, respectively $[5,6]$. These proteins share the same modular structure such that both bind $E_{2}$ and have significant sequence homology, especially in their DNA and ligand-binding domains. This bolstered the concept that ERs share a common motif and are members of a nuclear receptor family. To paraphrase Toran-Allerand [7], when there were only the two nuclear receptors, ER $\alpha$ and ER $\beta$, life seemed simple. However, even in those 'simple' times, it was known that ERs could interact with other transcription factors, namely Fos and Jun, which bind DNA at the activator protein-1 (AP-1) site, to regulate transcription independent of EREs [8].

Another story was developing in parallel. Early observations implicated $\mathrm{E}_{2}$ in rapid actions in a number of neuronal and nonneuronal cells. For example, $\mathrm{E}_{2}$ membrane signaling rapidly increased levels of cAMP in the uterus [9], altered neuronal firing of hypothalamic neurons [10] and augmented the release of neuropeptides [11]. In the past two decades, there has been an explosion in the discovery of putative membrane ERs (mERs) that mediate $\mathrm{E}_{2}$ membrane signaling. Many have been variants of ESR1 and ESR2, but others appear to be completely novel proteins. Several of these have been proposed as mERs, including classical ER $\alpha$ and ER $\beta$ or splice variants [12-14], G protein-coupled receptor 30 [15], Gq-mER [16, 17], and ER-X [18]. In addition, it has become clear that mERs can interact with other membrane receptors including insulin-like growth factor-1 receptor [19] and metabotropic glutamate receptors [20]. These $\mathrm{mER}$ candidates activate a variety of signaling pathways including phospholipase $\mathrm{C}$, protein kinase $\mathrm{C}(\mathrm{PKC})$, protein kinase $\mathrm{A}(\mathrm{PKA})$ and MAP kinase signaling cascades [21-23]. As a starting point, we will stipulate that all $\mathrm{mERs}$ bind $\mathrm{E}_{2}$. While it would be very helpful to have a universal mER antagonist, at present none of the putative antagonists appears to be the 'silver bullet' naloxone has been for the opioid receptor field [24]. The most reliable ER antagonist has been ICI 182, 780 (fulvestrant), but some have noted agonist properties, especially at the ER-X putative mER [18]. This review is an attempt to synthesize our understanding of mERs in hypothalamic functions, to see whether a more complete picture of mERs will emerge.

\section{$E_{2}$ Membrane Signaling and Reproduction}

\section{$E_{2}$ Membrane Signaling and GnRH Secretion}

An acute direct effect of $E_{2}$ on neuronal activity in $\mathrm{GnRH}$ neurons from the guinea pig arcuate nucleus of the hypothalamus (ARH) was first described over 25 years ago [25] (reviewed in [21]). $\mathrm{E}_{2}$ rapidly hyperpolarizes GnRH neurons in guinea pigs via activation of inwardly-rectifying $\mathrm{K}^{+}$channels $[25,26]$. In mice, physiological concentrations (pM) of $E_{2}$ rapidly augment $K_{\text {ATP }}$ channel activity to hyperpolarize $\mathrm{GnRH}$ neurons via PKC and PKA signaling pathways, which are also activated by the selective Gq-mER ligand STX [27]. The $\mathrm{K}^{+}$ channel-mediated hyperpolarization is potentially involved in the recruitment of excitatory channels that are critical for burst firing of GnRH neurons including Ttype calcium channels $[28,29]$. Nanomolar concentrations of $\mathrm{E}_{2}$ enhance action potential firing by modulating intrinsic afterhyperpolarizing and afterdepolarizing potentials via a PKA-dependent mechanism involving ER $\beta$ [30]. When synaptic input is not blocked, picomolar concentrations of $E_{2}$ inhibit action potentials via an ER $\alpha$ dependent mechanisms [30]. In addition, $\mathrm{E}_{2}$ via $\mathrm{ER} \beta$ and/ or GRP30 rapidly potentiates high-voltage-activated $\mathrm{Ca}^{2+}$ currents (L- and R-type $\mathrm{Ca}^{2+}$ channels), suggesting that $\mathrm{Ca}^{2+}$ signaling is also a target for $\mathrm{E}_{2}$ membrane signaling GnRH neurons [31].

In primate and mouse olfactory placode $\mathrm{GnRH}$ (immature) neurons, $\mathrm{E}_{2}$ modulates $\mathrm{Ca}^{2+}$ oscillations, which synchronize with a periodicity of approximately $60 \mathrm{~min}$ [32-34], a rhythm similar to the pulsatile GnRH release $[35,36]$. Furthermore, nanomolar concentrations of a membrane-delimited $\mathrm{E}_{2}\left(\mathrm{E}_{2}\right.$-dendrimer $)$ alter the patterns of $\mathrm{Ca}^{2+}$ oscillations in primate $\mathrm{GnRH}$ neurons [37]. The $\mathrm{E}_{2}$ membrane signaling modulation of $\mathrm{Ca}^{2+}$ oscillations in primate $\mathrm{GnRH}$ neurons is suppressed by pertussis toxin treatment, attenuated by knockdown of GPR30 mRNA and partially mimicked by the GPR 30 agonist G1 [38]. $\mathrm{Ca}^{2+}$ oscillations are blocked by ICI 182,780 , mimicked by $\mathrm{E}_{2}$-BSA and blocked by pertussis toxin in immature mouse GnRH neurons [33, 34]. However, in adult mouse GnRH neurons, nanomolar concentrations of $E_{2}$ increase $\mathrm{Ca}^{2+}$ transients via presumably presynaptic GABA input [39]. The $\mathrm{E}_{2}$-mediated effects on $\mathrm{Ca}^{2+}$ oscillations are maintained in ER $\beta K O$ mice [39]. However, $\mathrm{E}_{2}$ activation of cAMP response element-binding protein (CREB) in mouse GnRH neurons is absent in ER $\beta K O$ mice [40]. In addition, Terasawa and colleagues [38, 41] have found that GPR30 and the Gq-coupled mER are also involved based on the findings that G1 and STX increase calcium oscillations and $\mathrm{GnRH}$ release from monkey placode neurons.

Although $\mathrm{E}_{2}$ membrane signaling may be involved in negative feedback, it has been difficult to put ER $\beta$-, GPR30- or Gq-mER-dependent signaling into a physio- 
logical context of estrogen-positive feedback, which is absent in mice with either global or neuronal-specific ER $\alpha$ knockdown [42]. These observations prima facie suggest that activation of female reproduction requires ER $\alpha$-mediated $\mathrm{E}_{2}$ actions in neurons. However, these gene deletion experiments may not necessarily mean that only $\mathrm{ER} \alpha$ is involved. Clearly, $\mathrm{ER} \alpha$ is a transcription factor affecting hundreds of genes important for cell signaling $[43,44]$. Some of these genes may be essential for a mERinitiated response that normally contributes to female reproduction but is defective in $\mathrm{ER} \alpha \mathrm{KO}$ mice.

In addition to the idea that $\mathrm{E}_{2}$ directly influences neurons to elicit both positive and negative feedback on GnRH neuronal activity, recent evidence supports the idea that $\mathrm{E}_{2}$ acts through a glial-neuronal network that provides an appropriate local hormonal environment for an LH surge $[45,46]$. This hypothesis rests on the observation that $\mathrm{E}_{2}$ facilitates progesterone synthesis in mature hypothalamic astrocytes, which if prevented abrogates estrogen positive feedback of the LH surge in rodents [45-48]. In astrocytes, $\mathrm{E}_{2}$ membrane signaling is dependent on the interaction of ER $\alpha$ and mGluRla, which induces a rapid release of $\mathrm{IP}_{3}$ receptor-sensitive $\mathrm{Ca}^{2+}$ stores required for progesterone synthesis [49-51]. At physiologically relevant $(\mathrm{pM})$ concentrations, $\mathrm{E}_{2}$ elevation of $\left[\mathrm{Ca}^{2+}\right] \mathrm{i}$ is blocked with LY367,385 [(S)-(+)-aamino-4-carboxy-2-methylbenzeneacetic acid], a mGlu$\mathrm{R} 1 \mathrm{a}$ antagonist. While glutamate is not required for $\mathrm{E}_{2}$ action, DHPG [(S)-3,5-dihydroxyphenylglycine], an mGluRla agonist, augments the $\mathrm{Ca}^{2+}$ and progesterone responses to $\mathrm{E}_{2}$ stimulation in vitro $[51,52]$. These results suggest that elevation of local glutamate, presumably through neuronal activity, increases the amount of progesterone released. This would potentially generate a larger estrogen-positive feedback response. Interestingly, STX also increases $\mathrm{Ca}^{2+}$ release and stimulates progesterone synthesis in primary adult hypothalamic cultures, mimicking the actions of $E_{2}$ [53]. The activation of a novel Gq-mER signaling pathway by STX is blocked by the mGluRla antagonist, LY367,385, suggesting convergent $\mathrm{E}_{2}$ membrane signaling in astrocytes (reviewed in [46]).

\section{Estrogen Membrane Signaling and Sex Behavior}

Traditionally, nuclear-initiated $\mathrm{E}_{2}$ signaling was considered sufficient for female sexual receptivity - lordosis in rodents. This behavior, characterized by the ventral arching of the spine in response to mounting by a male, is displayed during behavioral estrus and is controlled by $\mathrm{E}_{2}$ through a complex hypothalamic circuitry involving

Estrogen Membrane Signaling in

Hypothalamus the ARH, medial preoptic nucleus (MPN) and the ventromedial nucleus of the hypothalamus (VMH) $[52,54]$. Within the past decade, it has become clear that in addition to the direct nuclear actions of $E_{2}$ in these various nuclei, membrane-initiated signaling is important for sexual behavior. One thought is that the initial $\mathrm{E}_{2}$ membrane signaling activates a signaling cascade (PKA and $\mathrm{PKC}$ ) in VMH neurons that augments the nuclear-mediated $\mathrm{E}_{2}$ signaling and lordosis behavior [55]. One mechanism highlights the potential importance of growth factors mediating actions of $\mathrm{E}_{2}$. $\mathrm{E}_{2}$ activates IGF-I, IGF-I receptors and induces the association between IGF-1 receptors and $\mathrm{ER} \alpha[19,56-58]$, leading to phosphatidylinositol 3-kinase and protein kinase B/Akt activation, and facilitation of lordosis behavior [57-59].

A model of $E_{2}$ membrane signaling that explains both facilitatory and inhibitory actions proposes that classical $\mathrm{ER} \alpha$ or ER $\beta$ at the cell membrane transactivates mGluRs to initiate cell signaling (fig. 1) $[20,23]$. This ER $\alpha$-mGluR interaction regulates the hypothalamic circuitry controlling female sexual receptivity [60]. ER $\alpha$ and mGluRla are coexpressed in ARH cells and can be coimmunoprecipitated from membrane fractions [51, 60, 61]. Blocking either ERs or mGluRla in the ARH prevents the rapid PKC phosphorylation and activation of MPN projecting proopiomelanocortin (POMC; the precursor of $\beta$-endorphin) neurons that are responsible for activating/internalizing $\mu$-opioid receptors (MOR) [62-64]. Similarly, activation of ARH neurons with a membrane-impermeant $\mathrm{E}_{2}$ or DHPG stimulates MOR internalization [60]. These MPN MOR neurons, in turn, project to the VMH (Sinchak et al., unpubl. findings), and the transient activation of MOR is necessary for full sexual receptivity that is apparent 30-48 $\mathrm{h}$ after $\mathrm{E}_{2}$ treatment [65]. While full sexual receptivity also requires $\mathrm{E}_{2}$-induced gene transcription, one question about membrane-initiated $\mathrm{E}_{2}$ action is how the transient $\mathrm{E}_{2}$-induced activation and internalization of MOR in the MPN facilitates full sexual receptivity at the later time points. One possible explanation is that MOR activation produces a transient inhibition of the MPN neurons that project to the VMH. These neurons rebound from a hyperpolarized state with facilitated firing that excites VMH neurons, ultimately facilitating sexual receptivity.

In the rat $\mathrm{ARH}, \mathrm{E}_{2}$ activation of POMC neurons involves the activation of the NPY-Y1 receptor [64]. While a direct $\mathrm{E}_{2}$ action on POMC neurons cannot be ruled out, one hypothesis is that $\mathrm{E}_{2}$ activates the $\mathrm{ER} \alpha$ mGluRla complex in the ARH initiating multiple signaling pathways, including a $\mathrm{Ca}^{2+}$-independent $\mathrm{PKC} \theta$ 


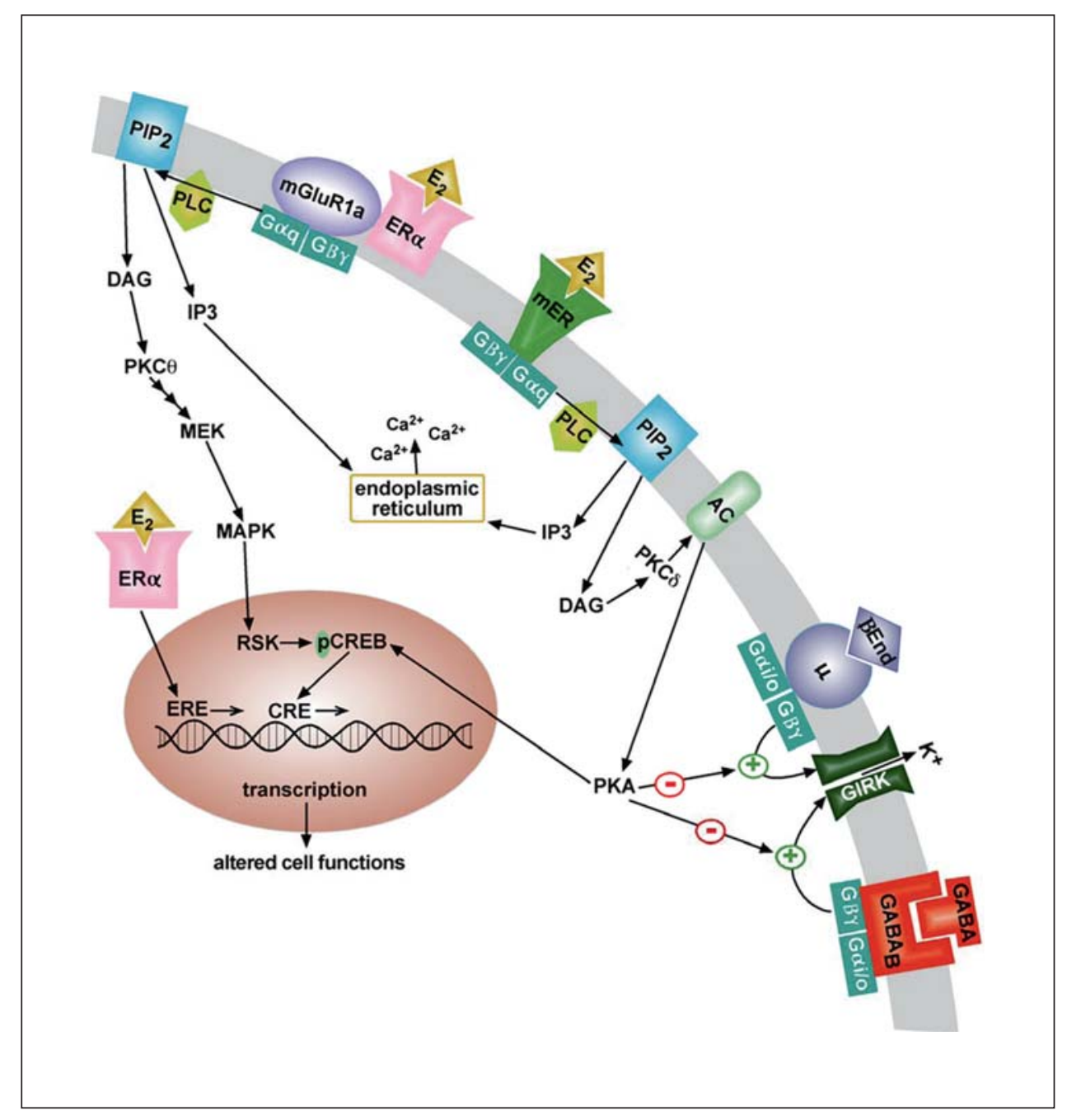

Fig. 1. Proposed schema of $E_{2}$ signaling in POMC neurons. As in other nonneural cells, $\mathrm{E}_{2}$ binds to intracellular $\mathrm{ER} \alpha$ to activate genes via EREs. In addition, $\mathrm{E}_{2}$ binds to $\mathrm{ER} \alpha$ localized at the neuronal (plasma) membrane and activates group 1 metabotropic glutamate receptor (mGluR1a) signaling. Activation of mGluR1a causes G $\alpha$ q stimulation of phospholipase C (PLC), which leads to the hydrolysis of membrane-bound phosphatidylinositol 4,5-biphosphate (PIP2) to inositol 1,4,5 triphosphate (IP3) and diacylglycerol (DAG). IP3 releases internal calcium $\left(\mathrm{Ca}^{2+}\right)$ stores, while DAG activates PKC $\theta$, leading to mitogen-activated kinase kinase (MEK) to mitogen-activated kinase (MAPK) to ribosomal S6 kinase (RSK)-induced phosphorylation of CREB. pCREB will acti-

[66]. Activating PKC $\theta$ in the ARH appears to be necessary for lordosis behavior since blocking PKC $\theta$ in the $\mathrm{ARH}$ abrogates MOR internalization and prevents lordosis behavior [66]. Activation of protein kinases is critical for not only lordosis behavior [55, 66-68], but also for feeding behavior (described below). These data col- vate genes expressing CREB-response elements (CREs). Also, $\mathrm{E}_{2}$ activates a mER that is $\mathrm{G} \alpha_{\mathrm{q}}$-coupled (Gq-mER) to activate PLC generating IP3 and DAG. $\mathrm{Ca}^{2+}$ is released from the endoplasmic reticulum by IP3, and DAG activates PKC $\delta$. Through phosphorylation, adenylyl cyclase (AC) activity is upregulated by PKC $\delta$. The generation of cAMP activates PKA, which through phosphorylation can rapidly uncouple $\mathrm{GABA}_{\mathrm{B}}$ and $\mu$-opioid $(\mu)$ receptors from $\mathrm{G}$ protein-coupled, inwardly rectifying $\mathrm{K}^{+}$(GIRK) channels. Gq-mER-mediated activation of PKA can also phosphorylate CREB. Therefore, in addition to the direct effects on membrane excitability, both mGluR1 and mER signaling pathways can alter gene transcription through CREs on genes. lectively suggest that the membrane-initiated interactions of the ER $\alpha$-mGluRla complex via a PKC-mediated pathway are a component of the $\mathrm{E}_{2}$ control of MOR internalization in the MPN and the regulation of lordosis behavior. 


\section{Estrogen Membrane Signaling and Energy Homeostasis}

Besides reproduction, $\mathrm{E}_{2}$ controls a number of hypothalamic-regulated autonomic functions including energy homeostasis, the balance between energy intake and energy expenditure. $E_{2}$ signaling via $E R \alpha$ is a necessary component of the regulation of energy homeostasis [69]. A loss-of-function mutation in $\mathrm{ER} \alpha$ has a clear metabolic phenotype in man with expression of type 2 diabetes, hyperinsulinemia and obesity [70]. However, global reinstatement of an ER $\alpha$ that is lacking the ERE targeting domain is sufficient for 'rescuing' the metabolic deficits in mice [71]. These findings suggest an important role for non-ERE-mediated $E_{2}$ signaling. Moreover, brain-specific knockout of ER $\alpha$ causes hyperphagia and hypometabolism, and selective knockdown of ER $\alpha$ in POMC neurons recapitulates the hyperphagic phenotype in female mice [72]. A caveat is that POMC-Cre is also expressed in progenitor neurons that are destined to become NPY and perhaps other hypothalamic neurons [73]. Thus, the neuronal site of action of ER $\alpha$ in the control of energy homeostasis remains ambiguous.

Besides the nuclear-initiated $\mathrm{ER} \alpha$ signaling, compelling results point to a role for estrogen membrane signaling in the control of energy homeostasis. For example, $\mathrm{E}_{2}$ attenuates food intake within $4-6 \mathrm{~h}$ of administration into the third ventricle in fasted ovariectomized rats and mice $[74,75]$. A Gq-mER signaling pathway has been elucidated in hypothalamic POMC neurons that is activated within minutes $[16,17,76]$. This pathway was first characterized in guinea pigs and later shown in wild-type (C57BL/6), ER $\alpha / \beta$ double-knockout and GPR30 knockout mice $[16,76,77]$. This Gq-mER signaling pathway is blocked by the antiestrogen ICI 182,780 [16, 17], which at present is a sine qua non for an ER-mediated response. Gq-mER through PLC-PKC-PKA pathways attenuates the $\mathrm{GABA}_{\mathrm{B}}$ receptors and MOR activation of $\mathrm{G}$ proteincoupled inwardly rectifying $\mathrm{K}^{+}$(GIRK) channels (fig. 1). The resulting attenuation of inhibitory presynaptic inputs increases the excitability of the anorectic POMC neurons.

Moreover, the high-affinity (subnanomolar affinity for $E_{2}$ [16]) Gq-mER is selectively activated by STX, an analogue of 4-OH tamoxifen, which has an even greater (20-fold) affinity for Gq-mER and no measureable binding affinity for classical ERs [78]. STX, similar to $\mathrm{E}_{2}$, reduces postovariectomy weight gain, inhibits food intake by reducing meal frequency, reduces abdominal fat accumulation, maintains bone density and reduces core body temperature in ovariectomized female guinea pigs [76,
$79,80]$. Furthermore, the STX-initiated signaling pathway alters the transcription of a plethora of ARH genes involved in the control of homeostatic functions [79] (fig. 1). Therefore, Gq-mER appears to be a key player in mediating the effects of $E_{2}$ on hypothalamic neurons (POMC, NPY, etc.) controlling homeostatic functions.

\section{Conclusion}

The hypothalamic regulation of homeostatic functions has traditionally been regarded as mediated by direct nuclear actions of $\mathrm{E}_{2}$, which has been the dogma for decades. However, recent results indicate that $\mathrm{E}_{2}$ actions in the hypothalamus are a composite of membrane-initiated signaling and direct nuclear effects. Although somewhat unusual for the nuclear receptor field, the idea of multiple receptors, using multiple signaling strategies is commonplace among other receptor families. For example, glutamate has several families of ionotropic and metabotropic receptors. $E_{2}$ activates a cornucopia of different membrane-associated molecules that affect cell function. It is unusual, however, that the same molecules are used as both nuclear and mERs. In many ways, the mER field is still in its infancy, which raises the question: 'Which of the putative receptors are present on the membrane and how do they signal?'. For example, although $\mathrm{ER} \alpha$ and $\mathrm{ER} \beta$ have been localized in signaling complexes associated with the cell membrane [14, 49,51, 61], some controversy exists whether GPR30 (GPER1) is localized to the cell membrane. This is in spite of the fact that GRP30 resembles the canonical $G$ protein-coupled receptor structure. One possibility is that GRP30 is localized on smooth endoplasmic reticulum, and $\mathrm{E}_{2}$ activation directly releases intracellular $\mathrm{Ca}^{2+}$ stores. In this way GRP30 mediates rapid $\mathrm{E}_{2}$ action, but not at the cell membrane [81].

It is expected that these various ERs will have some measure of interaction. However, how and at what level these receptors interact is at present unclear. Certainly, activation of ER $\alpha$-mGluR1a or Gq-mER stimulates signaling cascades that can phosphorylate CREB and thus regulate gene expression independent of ERE (fig. 1). But how is this transcriptional activity integrated with activation of ERE and stabilization of the AP-1 site hallmarks of direct nuclear action? Is there an adaptive advantage of estrogen membrane signaling-mediated gene expression? Over the years, the steroid receptor field has been hindered by technical limitations in addition to the dogma about nuclear-initiated signaling. However, with the advent of new technologies we realize that $\mathrm{E}_{2}$ alters the ac- 
tivity of a large number of proteins - most of whose functions, in a physiological sense, are unknown. Integrating these global changes is the next big challenge for the field. The localization of ERs, broadly defined, throughout the nervous system suggests that their functions are critical. Indeed, the ability of nervous tissue to synthesize steroids, and in particular $\mathrm{E}_{2}$, also argues that these messengers are vital.

\section{Acknowledgements}

Research in the authors' laboratories was funded by grants from the National Institutes of Health: DA13185 (P.E.M.), HD04263 (P.E.M.), DK68098 (M.J.K.) and NS38809 (M.J.K.). The authors would like to thank Dr. Oline K. Ronnekleiv for her comments on earlier drafts of this review and also Martha A. Bosch for her help in preparing figure 1.

\section{References}

1 Simpkins JW, Singh M, Brock C, Etgen AM: Neuroprotection and estrogen receptors. Neuroendocrinology 2012;96:119-130.

- 2 Handa RJ, Mani SK, Uht RM: Estrogen receptors and the regulation of neural stress responses. Neuroendocrinology 2012;96: 111-118.

-3 Woolley CS: Acute effects of estrogen on neuronal physiology. Annu Rev Pharmacol Toxicol 2007;47:657-680.

4 Jensen EV, DeSombre ER: Estrogen-receptor interaction. Science 1973;182:126-134.

5 Walter P, Green S, Greene G, Krust A, Bornert JM, Jeltsch JM, Staub A, Jensen E, Scrace G, Waterfield M, Chambon P: Cloning of the human estrogen receptor cDNA. Proc Natl Acad Sci USA 1985;23:7889-7893.

-6 Kuiper GG, Enmark E, Pelto-Huikko M, Nilsson S, Gustafsson JÅ: Cloning of a novel estrogen receptor expressed in rat prostate and ovary. Proc Natl Acad Sci USA 1996;93: 5925-5930.

7 Toran-Allerand CD: Minireview: A plethora of estrogen receptors in the brain: where will it end? Endocrinology 2004; 145:1069-1074.

-8 Kushner PJ, Agard DA, Greene GL, Scanlan TS, Shiau AK, Uht RM, Webb P: Estrogen receptor pathways to AP-1. J Steroid Biochem Mol Biol 2000;74:311-317.

$\checkmark$ Szego CM, Davis JS: Adenosine 3',5'monophosphate in rat uterus: acute elevation by estrogen. Proc Natl Acad Sci USA 1967;58: 1711-1718.

10 Kelly MJ, Moss RL, Dudley CA: Differential sensitivity of preoptic-septal neurons to microelectrophoresed estrogen during the estrous cycle. Brain Res 1976;114:152-157.

-11 Micevych PE, Matt DW, Go VL: Concentration of cholecystokinin, substance $\mathrm{P}$, and bombesin in discrete regions of male and female rat brain: sex differences and estrogen effects. Exp Neurol 1988;100:416-425.

$\checkmark 12$ Skipper JK, Young LJ, Bergerson JM, Tetzlaff MT, Osborn CT, Crews D: Identification of an isoform of the estrogen receptor messenger RNA lacking exon four and present in the brain. Proc Natl Acad Sci USA 1993;90:71727175 .
Gorosito S, Lorenzo AG, Cambiasso MJ: Es-
trogen receptor alpha is expressed on the cell-surface of embryonic hypothalamic neurons. Neurosci 2008;154:1173-1177.

14 Bondar G, Kuo J, Hamid N, Micevych P: Estradiol-induced estrogen receptor-alpha trafficking. J Neurosci 2009;29:1532315330.

15 Filardo EJ, Quinn JA, Bland KI, Frackelton ARJ: Estrogen-induced activation of Erk-1 and Erk- 2 requires the $G$ protein-coupled receptor homolog, GPR30, and occurs via trans-activation of the epidermal growth factor receptor through release of HB-EGF. Mol Endocrinol 2000;14:1649-1660.

16 Lagrange AH, Rønnekleiv OK, Kelly MJ: Modulation of $\mathrm{G}$ protein-coupled receptors by an estrogen receptor that activates protein kinase A. Mol Pharmacol 1997;51:605-612.

17 Qiu J, Bosch MA, Tobias SC, Grandy DK, Scanlan TS, Rønnekleiv OK, Kelly MJ: Rapid signaling of estrogen in hypothalamic neurons involves a novel $G$ protein-coupled estrogen receptor that activates protein kinase C. J Neurosci 2003;23:9529-9540.

18 Toran-Allerand CD, Guan X, MacLusky NJ, Horvath TL, Diano S, Singh M, Connolly ES Jr, Nethrapalli IS, Tinnikov AA: ER-X: a novel, plasma membrane-associated, putative estrogen receptor that is regulated during development and after ischemic brain injury. J Neurosci 2002;22:8391-8401.

19 Quesada A, Etgen AM: Functional interactions between estrogen and insulin-like growth factor-I in the regulation of alpha1Badrenoceptors and female reproductive function. J Neurosci 2002;22:2401-2408.

20 Boulware MI, Weick JP, Becklund BR, Kuo SP, Groth RD, Mermelstein PG: Estradiol activates group I and II metabotropic glutamate receptor signaling, leading to opposing influences on cAMP response element-binding protein. J Neurosci 2005;25:5066-5078.

21 Rønnekleiv OK, Kelly MJ: Diversity of ovarian steroid signaling in the hypothalamus. Front Neuroendo 2005;26:65-84.

22 Kelly MJ, Rønnekleiv OK: Membrane-initiated estrogen signaling in hypothalamic neurons. Mol Cell Endocrinol 2008;290:1423.
23 Micevych PE, Mermelstein PG: Membrane estrogen receptors acting through metabotropic glutamate receptors: an emerging mechanism of estrogen action in brain. Mol Neurobiol 2008;38:66-77.

24 Goldstein A, Naidu A: Multiple opioid receptors: ligand selectivity profiles and binding site signatures. Mol Pharm 1989;36:265-272.

25 Kelly MJ, Rønnekleiv OK, Eskay RL: Identification of estrogen-responsive LHRH neurons in the guinea pig hypothalamus. Brain Res Bull 1984;12:399-407.

26 Lagrange AH, Rønnekleiv OK, Kelly MJ: Estradiol-17beta and mu-opioid peptides rapidly hyperpolarize GnRH neurons: a cellular mechanism of negative feedback? Endocrinology 1995;136:2341-2344.

27 Zhang C, Kelly MJ, Rønnekleiv OK: 17 $\beta$ estradiol rapidly increases adenosine $5^{\prime}$ triphosphate-sensitive potassium channel activity in gonadotropin-releasing hormone neurons via a protein kinase signaling pathway. Endocrinology 2010;151:4477-4484.

28 Zhang C, Bosch MA, Levine JE, Rønnekleiv OK, Kelly MJ: Gonadotropin-releasing hormone neurons express $K_{A T P}$ Channels that are regulated by estrogen and responsive to glucose and metabolic inhibition. J Neurosci 2007;27:10153-10164.

29 Zhang C, Bosch MA, Rick EA, Kelly MJ, Rønnekleiv OK: 17Beta-estradiol regulation of T-type calcium channels in gonadotropinreleasing hormone neurons. J Neurosci 2009; 29:10552-10562.

30 Chu Z, Andrade J, Shupnik MA, Moenter SM: Differential regulation of gonadotropinreleasing hormone neuron activity and membrane properties by acutely applied estradiol: dependence on dose and estrogen receptor subtype. J Neurosci 2009;29:56165627.

31 Sun J, Chu Z, Moenter SM: Diurnal in vivo and rapid in vitro effects of estradiol on voltage-gated calcium channels in gonadotropin-releasing hormone neurons. J Neurosci 2010;30:3912-3923. 
- 32 Terasawa E, Schanhofer WK, Keen KL, Luchansky LL: Intracellular $\mathrm{Ca}^{2+}$ oscillations in luteinizing hormone-releasing hormone neurons derived from the embryonic olfactory placode of the rhesus monkey. J Neurosci 1999;19:5898-5909.

- 33 Temple JL, Laing E, Sunder A, Wray S: Direct action of estradiol on gonadotropin-releasing hormone-1 neuronal activity via a transcription-dependent mechanism. J Neurosci 2004;24:6326-6333.

- 34 Temple JL, Wray S: BSA-estrogen compounds differentially alter gonadotropin-releasing hormone-1 neuronal activity. Endocrinology 2005; 146:558-563.

- 35 Levine JE, Norman RL, Gliessman PM, Oyama TT, Bangsberg DR, Spies HG: In vivo gonadotropin-releasing hormone release and serum luteinizing hormone measurements in ovariectomized, estrogen-treated rhesus macaques. Endocrinology 1985;117:711-721.

-36 Gearing M, Terasawa E: Luteinizing hormone releasing hormone (LHRH) neuroterminals mapped using the push-pull perfusion method in the rhesus monkey. Brain Res Bull 1988;21:117-121.

-37 Abe H, Keen KL, Terasawa E: Rapid action of estrogens on intracellular calcium oscillations in primate LHRH-1neurons. Endocrinology 2008;149:1155-1162.

38 Noel SD, Keen KL, Baumann DI, Filardo EJ, Terasawa E: Involvement of G-protein couple receptor 30 (GPR30) in rapid action of estrogen in primate LHRH neurons. Mol Endocrinol 2009;3:349-359.

39 Romanò N, Lee K, Ábrahám IM, Jasoni CL, Herbison AE: Non-classical estrogen modulation of presynaptic GABA terminals modulates calcium dynamics in gonadotropinreleasing hormone $(\mathrm{GnRH})$ neurons. Endocrinology 2008; 149:5335-5344.

-40 Abraham IM, Han SK, Todman MG, Korach KS, Herbison AE: Estrogen receptor beta mediates rapid estrogen actions on gonadotropin-releasing hormone neurons in vivo. J Neurosci 2003;23:5771-5777.

-41 Kenealy BP, Keen KL, Rønnekleiv OK, Terasawa E: STX, a novel nonsteroidal estrogenic compound, induces rapid action in primate GnRH neuronal calcium dynamics and peptide release. Endocrinology 2011;152:182191.

-42 Wintermantel TM, Campbell RE, Porteous R, Bock D, Gröne H-J, Todman MG, Korach KS, Greiner E, Perez CA, Schutz G, Herbison AE: Definition of estrogen receptor pathway critical for estrogen positive feedback to gonadotropin-releasing hormone neurons and fertility. Neuron 2006;52:271-280.

$\checkmark 43$ Hewitt SC, Deroo BJ, Hansen K, Collins J, Grissom S, Afshari C, Korach KS: Estrogen receptor-dependent genomic responses in the uterus mirror the biphasic physiological response to estrogen. Mol Endocrinol 2003; 17:2070-2083.
44 Malyala A, Pattee P, Nagalla SR, Kelly MJ, Rønnekleiv OK: Suppression subtractive hybridization and microarray identification of estrogen regulated hypothalamic genes. Neurochem Res 2004;29:1189-1200.

-45 Micevych P, Sinchak K, Mills RH, Tao L, LaPolt P, Lu JK: The luteinizing hormone surge is preceded by an estrogen-induced increase of hypothalamic progesterone in ovariectomized and adrenalectomized rats. Neuroendocrinology 2003;78:29-35.

46 Micevych P, Sinchak K: The neurosteroid progesterone underlies estrogen positive feedback of the LH surge. Front Endocrinol 2011:2:1-11.

47 Sinchak K, Mills RH, Tao L, LaPolt P, Lu JK, Micevych P: Estrogen induces de novo progesterone synthesis in astrocytes. Dev Neurosci 2003;25:343-348.

48 Micevych P, Sinchak K: Estradiol regulation of progesterone synthesis in the brain. Mol Cell Endocrinol 2008;290:44-50.

49 Chaban VV, Lakhter AJ, Micevych P: A membrane estrogen receptor mediates intracellular calcium release in astrocytes. Endocrinology 2004; 145:3788-3795.

50 Micevych PE, Chaban V, Ogi J, Dewing P, Lu $\mathrm{JKH}$, Sinchak K: Estradiol stimulates progesterone synthesis in hypothalamic astrocyte cultures. Endocrinology 2007;148:782-789.

51 Kuo J, Hariri OR, Bondar G, Ogi J, Micevych P: Membrane estrogen receptor- $\alpha$ interacts with metabotropic glutamate receptor type 1a to mobilize intracellular calcium in hypothalamic astrocytes. Endocrinology 2009; 150:1369-1376

52 Micevych P, Dominguez R: Membrane estradiol signaling in the brain. Front Neuroendocrinol 2009;30:315-327.

53 Kuo J, Hamid N, Bondar G, Prossnitz ER, Micevych P: Membrane estrogen receptors stimulate intracellular calcium release and progesterone synthesis in hypothalamic astrocytes. J Neurosci 2010;30:12950-12957.

54 Blaustein JD, Erskine MS: Feminine sexual behavior: cellular integration of hormonal and afferent information in the rodent forebrain; in Pfaff D, Etgen AM, Fahrbach SE, Rubin RT (eds): Hormones, Brain and Behavior. San Diego, Academic Press, 2002, pp 139-214.

55 Kow LM, Pfaff DW: The membrane actions of estrogens can potentiate their lordosis behavior-facilitating genomic actions. Proc Natl Acad Sci USA 2004;101:12354-12357.

56 Quesada A, Etgen AM: Insulin-like growth factor-1 regulation of a1-adrenergic receptor signaling is estradiol dependent in the preoptic area and hypothalamus of female rats. Endocrinology 2001;142:599-607.

57 Cardona-Gomez GP, Mendez P, DonCarlos L, Azcoitia I, Garcia-Segura LM: Interactions of estrogen and insulin-like growth factor-I in the brain: molecular mechanisms and functional implications. J Steroid Biochem Mol Biol 2003;83:211-217.
58 Mendez P, Azcoitia I, Garcia-Segura LM: Estrogen receptor alpha forms estrogen-dependent multimolecular complexes with insulin-like growth factor receptor and phospatidylinositol 3-kinase in the adult rat brain. Mol Brain Res 2003;112:170-176.

59 Etgen AM, Acosta-Martinez M: Participation of growth factor signal transduction pathways in estradiol facilitation of female reproductive behavior. Endocrinology 2003; 144:3828-3835.

-60 Dewing P, Boulware MI, Sinchak K, Christensen A, Mermelstein PG, Micevych PE: Membrane estrogen receptor-alpha interactions with metabotropic glutamate receptor 1a modulate female sexual receptivity in rats. J Neurosci 2007;27:9294-9300.

61 Dominguez R, Micevych P: Estradiol rapidly regulates membrane estrogen receptor levels in hypothalamic neurons. J Neurosci 2010; 30:12589-12596.

-62 Eckersell CB, Popper P, Micevych PE: Estrogen-induced alteration of mu-opoid receptor immunoreactivity in the medial preoptic nucleas and medial amygdala. J Neurosci 1998; 18:3967-3976.

63 Sinchak K, Micevych PE: Progesterone blockade of estrogen activation of mu-opioid receptors regulates reproductive behavior. J Neurosci 2001;21:5723-5729.

64 Mills RH, Sohn RK, Micevych PE: Estrogeninduced mu-opioid receptor internalization in the medial preoptic nucleus is mediated via neuropeptide Y-Y1 receptor activation in the arcuate nucleus of female rats. J Neurosci 2004;24:947-955.

65 Sinchak K, Shahedi K, Dewing P, Micevych $\mathrm{PE}$ : Sexual receptivity is reduced in the female mu-opioid receptor knockout mouse. Neuroreport 2005;15:1697-1700.

66 Dewing P, Christensen A, Bondar G, Micevych $\mathrm{PE}$ : Protein kinase $\mathrm{C}$ signaling in the hypothalamic arcuate nucleus regulates sexual receptivity in female rats. Endocrinology 2008; 149:5934-5942.

67 Kow L-M, Mobbs CV, Pfaff DW: Roles of second-messenger systems and neuronal activity in the regulation of lordosis by neurotransmitters, neuropeptides, and estrogen: a review. Neurosci Biobehav Rev 1994; 18:251-268.

68 Vasudevan N, Kow LM, Pfaff D: Integration of steroid hormone initiated membrane action to genomic function in the brain. Steroids 2005;70:388-396.

69 Geary N, Asarian L, Korach KS, Pfaff DW, Ogawa S: Deficits in $\mathrm{E}_{2}$-dependent control of feeding, weight gain, and cholecystokinin satiation in ER-alpha null mice. Endocrinology 2001;142:4751-4757.

70 Smith EP, Boyd J, Frank GR, Takahashi H, Cohen RM, Specker B, Williams TC, Lubahn DB, Korach KS: Estrogen resistance caused by a mutation in the estrogen-receptor gene in a man. N Engl J Med 1994;331:1056-1061. 
-71 Park CJ, Zhao Z, Glidewell-Kenny C, Lazic M, Chambon P, Drust A, Weiss J, Clegg DJ, Dunaif A, Jameson JL, Levine JE: Genetic rescue of nonclassical ER $\alpha$ signaling normalizes energy balance in obese ER $\alpha$-null mutant mice. J Clin Invest 2011;121:604612.

72 Xu Y, Nedugadi TP, Zhu L, Sobhani N, Irani BG, Davis KE, Zhang X, Zou F, Gent LM, Hahner LD, Khan SA, Elias CF, Elmquist JK, Clegg DJ: Distinct hypothalamic neurons mediate estrogenic effects on energy homeostasis and reproduction. Cell Metab 2011;14: 453-465.

73 Padilla SL, Carmody JS, Zeltser LM: Pomcexpressing progenitors give rise to antagonistic neuronal populations in hypothalamic feeding circuits. Nat Med 2010;16:403-405.

74 Qiu J, Xue C, Bosch MA, Murphy JG, Fan W, Rønnekleiv OK, Kelly MJ: Serotonin 5HT2c receptor signaling in hypothalamic POMC neurons: role in energy homeostasis in females. Mol Pharm 2007;72:885-896.
75 Gao Q, Mezei G, Nie Y, Rao Y, Choi CS, Bechmann I, Leranth C, Toran-Allerand D, Priest CA, Roberts JL, Gao X-B, Mobbs C, Shulman GI, Diano S, Horvath TL: Anorectic estrogen mimics leptin's effect on the rewiring of melanocortin cells and Stat 3 signaling in obese animals. Nat Med 2006;13: 89-94.

76 Qiu J, Bosch MA, Tobias SC, Krust A, Graham S, Murphy S, Korach KS, Chambon P, Scanlan TS, Rønnekleiv OK, Kelly MJ: A G protein-coupled estrogen receptor is involved in hypothalamic control of energy homeostasis. J Neurosci 2006;26:5649-5655.

77 Qiu J, Rønnekleiv OK, Kelly MJ: Modulation of hypothalamic neuronal activity through a novel G-protein coupled estrogen membrane receptor. Steroids 2008;73:985-991.
Tobias SC, Qiu J, Kelly MJ, Scanlan TS: Synthesis and biological evaluation of SERMs with potent nongenomic estrogenic activity. ChemMedChem 2006;1:565-571.

-79 Roepke TA, Xue C, Bosch MA, Scanlan TS Kelly MJ, Rønnekleiv OK: Genes associated with membrane-initiated signaling of estrogen and energy homeostasis. Endocrinology 2008;149:6113-6124.

80 Roepke TA, Bosch MA, Rick EA, Lee B, Wagner EJ, Seidlová-Wuttke D, Wuttke W, Scanlan TS, Rønnekleiv OK, Kelly MJ: Contribution of a membrane estrogen receptor to the estrogenic regulation of body temperature and energy homeostasis. Endocrinology 2010;151:4926-4937.

81 Prossnitz, ER, Arteburn JB, Smith HO, Oprea TI, Sklar LA, Hathaway HJ: Estrogen signaling through the transmembrane $G$ protein-coupled receptor GPR30. Annu Rev Physiol 2008;70:165-190. 